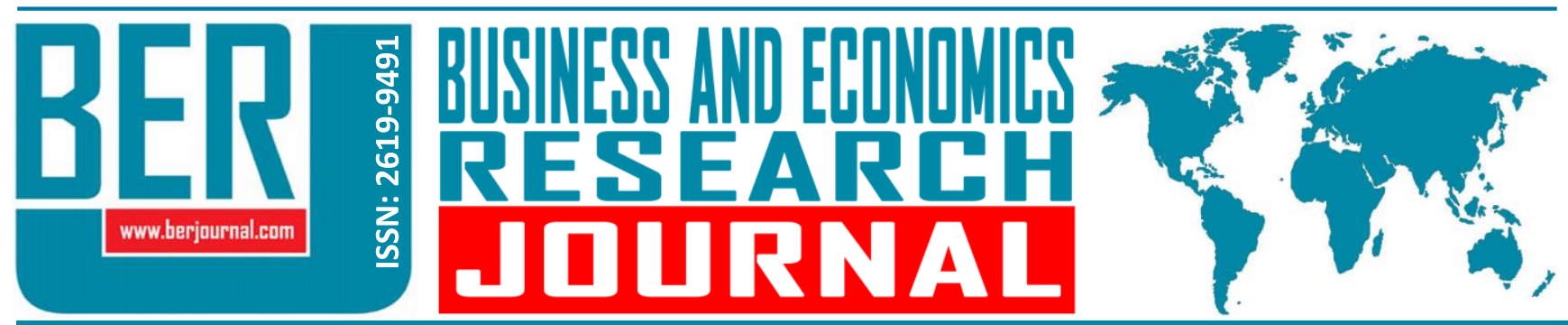

Business and Economics Research Journal Vol. 11, No. 2, 2020, pp. 479-494 doi: 10.20409/berj.2020.262

\title{
Çalışma Yaşamında Ayrımcılık: LGBT+ Bireylere Yönelik Nitel Bir Araştırma
}

\section{Duygu Acar Erdur ${ }^{\mathrm{a}}$, Faruk Ozgunlu}

Öz: Bu çalışma, Türkçe literatürde görece az çalışılan bir konu olan Türk çalışma yaşamında cinsel yönelim ayrımcılığına odaklanmaktadır. Çalışma kapsamında, aktif olarak çalışma hayatı içinde olan LGBT+ bireylerin cinsel yönelimlerinden dolayı karşılaştıkları ayrımcı davranışların var olup olmadığının ve var ise bunların neler olduğunun ortaya çıkarılması amaçlanmıştır. Tasarlanan nitel araştırma kapsamında kartopu örneklemesi ile ulaşılan toplam 17 LGBT+ birey ile bir görüşme protokolüne bağlı kalarak yarı yapılandırılmış görüşmeler gerçekleştirilmiştir. Bu görüşmelerden elde edilen veriler içerik analizi yoluyla analiz edilmiştir. Araştırmanın bulguları, beş temel noktayı işaret etmektedir. Bulgular ilk olarak, LGBT+ bireylerin çalışma yaşamında cinsel yönelimlerinden dolayı işe alma/işten çıkarma gibi formel ayrımcılıkla karşı karıya kaldıklarını göstermektedir. Ayrıca bulgular, LGBT+ bireylerin çalışma ortamında küçümseme/hakarete uğrama gibi informel ayrımcılığa uğradıklarını da ortaya koymaktadır. Bununla birlikte, Türk çalışma ortamında homofobinin var olduğu anlaşılmaktadır. LGBT+ bireylerin bu tür davranışlarla başa çıkabilmek için belirli mekanizmalardan yararlandığını ve genellikle çalışma hayatında cinsel kimliklerini gizleme eğiliminde oldukları tespit edilmiştir. Son olarak bulgular, LGBT+ bireylerin bu süreçten psikolojik olarak olumsuz etkilendiklerine işaret etmektedir.

\section{Discrimination in Work life: A Qualitative Research on LGBT+ Individuals}

\begin{abstract}
This study focuses on sexual orientation discrimination in the Turkish work life, which is a relatively less studied subject in Turkish literature. The study aims to determine the discriminatory behaviors against LGBT + individuals who are in active work life due to their sexual orientation if any. The study follows a qualitative research design. Based on an interview protocol, semi-structured interviews were conducted with 17 LGBT+ individuals using a snowball sampling method. Content analysis of the data emphasizes five distinct issues. First, it is determined that LGBT+ individuals in Turkish work life are subjected to formal discrimination in such as recruitment, dismissal processes. Findings also demonstrate that LGBT+ individuals are subject to informal discrimination through disdain, insult, etc. behaviors. Additionally, the findings of the study indicate a homophobic work environment in the Turkish context. Moreover, it is found that LGBT+ individuals use various mechanisms to cope with discriminatory behavior at the workplace, and mostly tend to conceal their sexual orientations. Finally, findings reveal that this process affects LGBT+ individuals in a negative way.
\end{abstract}

\section{Anahtar Sözcükler: Ayrımcılık, Çalışma Yaşamında Ayrımcılık, Cinsel Yönelim Ayrımcılığı, LGBT+, Nitel Araştırma}

JEL: J70, J71, M14

$\begin{array}{ll}\text { Geliş } & : \text { 18 Ekim } 2019 \\ \text { Düzeltme } & : 29 \text { Kasım } 2019 \\ \text { Kabul } & : 17 \text { Aralık } 2019 \\ & \\ \text { Tür } & : \text { Araştırma }\end{array}$

Keywords: Discrimination, Discrimination in the Work Life, Sexual Orientation Discrimination, LGBT + Qualitative Research

JEL: J70, J71, M14

Received : 18 October 2019

Revised : 29 November 2019

Accepted : 17 December 2019

Type : Research

a Asst. Prof., PhD., Beykent University, Faculty of Economics and Administrative Sciences, Business Administration Department, Istanbul, Turkiye, duyguerdur@beykent.edu.tr (ORCID ID: 0000-0002-4288-4401)

b Graduate Student, Beykent University, The Institute of Social Sciences, Business Administration Program, Istanbul, Turkiye, farukozgunlu@gmail.com (ORCID ID: 0000-0002-2867-9292) 


\section{Giriş}

Ayrımcılık, çalışma yaşamında halen gözlenen köklü sorunlarından biri olmayı sürdürmektedir. Pek çok araştırma bireylerin, cinsiyet, yaş, engellilik durumu, etnik köken, ırk, din, sosyal statü, medeni durum vb. temelinde çalışma yaşamında ayrımcı davranışlara maruz kaldığını göstermektedir. Bu çalışma, cinsiyet, yaş, engellilik gibi boyutlara kıyasla literatürde daha az çalışılan cinsel yönelim ayrımcııı̆ına odaklanmaktadır. Her ne kadar Türk ayrımcılık yazınında çalışma yaşamında cinsel yönelim ayrımcılığını konu edinen çalışmaların sayısında son yıllarda artış gözlense de yabancı yazınla karşılaştııılı̆̆ında ülkemizde bu çalışmaların halen sayıca az olduğu görülmektedir. Bu noktadan hareketle çalışmada, toplumsal düzen içerisinde norm olarak kabul edilen heteroseksüelliğin dışındaki cinsel yönelimlere sahip olan bireyler konu edinilmektedir.

LGBT+ (Lezbiyen, Gey, Biseksüel, Transeksüel ve devamı/diğerleri) bireyler toplum içinde en fazla ötekileştirilen ve dışlanan gruplardan birini oluşturmaktadır. LGBT+ bireylerin cinsel yönelimleri nedeniyle ayrımcılığa uğramalarına engel olmak ve hak alanlarını genişletmek için uluslararası ve ulusal düzeyde çeşitli çalışmalar var olsa da bu çabalar ayrımcılığın ortadan kalması için yeterli olamamıştır. Özellikle, yasal olarak en az korunan azınlık gruplarından biri olarak LGBT+ bireyler halen ayrımcı davranışlara maruz kalabilmektedirler. Son yıllarda ülkemizde de LGBT+ hareketin gelişmesine, söz konusu bireylerin görünürlüklerinde ve toplumsal olarak kabul edilirliklerinde olumlu gelişmeler yaşanmasına rağmen, LGBT+ bireyler halen dışlanma, taciz ve şiddet gibi durumlarla karşı karşıya kalmaktadırlar. LBGT+ bireylere yönelik ayrımcı davranışların en yoğun gözlendiği alanlardan biri de çalışma yaşamıdır.

Yukarıdaki çerçeveden hareketle bu çalışma, LGBT+ bireylerin çalışma yaşamında cinsel yönelimleri nedeniyle maruz kaldıkları ayrımcı davranışların neler olduğunun ortaya çıkarılmasını amaçlamaktadır. Bununla birlikte, LGBT+ bireylerin maruz kaldıkları ayrımcı davranışların hangi süreçlerde gerçekleştiğinin ortaya çıkarılması hedeflenmektedir. Buna ek olarak, LGBT+ bireylerin, çalışma ortamında karşılaştıkları ayrımcı davranışlarla nasıl başa çıktıkları ve bundan nasıl etkilendikleri hakkında fikir edinilmeye çalışılmaktadır.

Bu kapsamda, çalışmanın izleyen bölümü kavramsal çerçeveye ayrılmıştır. Bu kısımda, genel olarak çalışma yaşamında ayrımcılık kavramına yer verilmekte ve ayrımcılığın çalışma yaşamındaki yansımaları hakkında bilgi verilmektedir. Bununla birlikte, bu makalenin konusunu oluşturması nedeniyle cinsel yönelim kavramı açıklanmakta ve cinsel yönelim ayrımcılığııın kaynakları tartışımaktadır. Devamında ise cinsel yönelim ayrımcılığı ile ilgili yasal düzenlemelerin durumuna değinilmektedir. Bu kısımda ayrıca, yabancı ve Türkçe yazında yer alan önceki çalışmaların bulgularına yer verilmektedir. Çalışmanın devamında, tasarlanan nitel araştırmayla ilgili; araştırmanın amaç, yöntem ve örnekleme ilişkin bilgi verilmekte ve LGBT+ bireyler ile gerçekleştirilen yarı yapılandırılmış görüşmelerin bulguları paylaşılmakta ve genel bir değerlendirme yapılmaktadır.

\section{Kavramsal Çerçeve}

Son dönemde yaşanan demografik gelişmeler, küreselleşme, yetenek yönetimi gibi nedenlerle hem akademisyenlerin hem de uygulayıcıların ajandasına giren çeşitlilik yönetimi (Özbilgin ve Tatlı, 2008) ile birlikte ayrımcılık olgusu tekrar tartışımaktadır. Birçok farklı tanımı olmakla birlikte ayrımcılığı en yalın ifadeyle "eşit veya karşılaştırılabilir durumdaki kişilere farklı muamele yapılması" şeklinde tanımlamak mümkündür (Hervey, 1992: 27-28). Bir başka ifadeyle, ayrımclık, bir bireye sahip olduğu bir özellik nedeniyle diğerlerinden farklı davranılması şeklinde ifade edilebilir. Goldman, Gutek, Stein ve Lewis (2006: 802) ayrımcılığı grup üyeliği üzerinden tanımlayarak grup üyeliği nedeniyle bireye yönelik negatif davranışlar olarak ifade etmektedirler. Göregenli ve Karakuş (2011) de ayrımcılığı, bir gruba veya grubun üyelerine karşı önyargı temelli olumsuz tutum ve davranışlarla ilgili bir süreç olarak tanımlamıştır. Öyle ki ayrımcılık, bireysel farklııklardan ziyade algılanan grup özelliklerine dayalı olarak bir grup içerisindeki bireylere bir başka gruptaki bireylerden farklı muamele etmek olarak kavramsallaştırılmaktadır (Lahey, 2005: 2). Dolayısıyla genel olarak, grup üyelikleri nedeniyle bireylere küçümseyici özellikler yükleme veya grup üyeliği dışında algılayarak bireyleri dışlama ve ayırıma tabi tutma süreci olarak tanımlanmaktadır (Doğrul, 2007: 15). Ayrımcı davranışlar, ortama, koşullara ve hedef kitleyle ilişkilere göre türlü şekillerde somutlaşmaktadır. Bunlar 
temelsiz eleştiri, olumsuz etiketlerle aşağılama veya damgalama, mesafeli tutma, toplumsal kaynaklardan mahrum bırakma, saldırganlık, düşmanlık, dışlama gibi farklı davranış biçimlerinde kendini gösterebilmektedir. Ayrımclık, daha makro bir çerçevede, bir devlet ya da toplumun, diğerlerine sağlamış olduğu bazı hak ve ayrıcalıklardan bazı üyelerini yoksun bırakması olarak da tanımlanabilmektedir (Demirel, 2011: 5).

Çalışma yaşamında ayrımcılık genel olarak, işletme içerisinde belirli bireylere veya gruplara sunulan hak ve olanakların diğerlerine sunulmaması olarak ifade edilebilir (Özen-Kutanis ve Ulu, 2016). Daha açık bir ifade ile çalışma yaşamında ayrımcılık; cinsiyet, yaş, ırk, etnik köken, kültür, dil, cinsel yönelim gibi birincil faktörlerin yanında din, aile yapısı, gelir düzeyi, sosyal statü, siyasal görüş, iş deneyimi gibi ikincil faktörler nedeniyle çalışanlara karşı farklı davranışlar sergilenmesi olarak tanımlanmaktadır (Özgener, 2014: 244). Öner'e göre iş yaşamında ayrımcılık düşük performans notu verme, terfi engelleme, tazminat bedelini düşük ödeme, görev değişikliği, işten çıkarma, iş görüşmesine çağrılmama, işe almama gibi çeşitli şekillerde kendini gösterebilmektedir (Öner, 2015: 51). Ayrımcılık ile ilgili çalışmalar incelendiğinde, çalışma yaşamında cinsiyet, yaş, engellilik vb. temelli ayrımcılık gibi konulara yer verildiği ancak cinsel yönelim ayrımcılığının Türk araştırmacılar tarafından görece daha az incelenen bir konu olduğu görülmektedir. Oysa bu gruplardan her birine ayrıca dâhil olabilecek olmakla birlikte cinsel yönelimin, en yaygın ayrımcılık sebeplerinden biri olduğu kabul edilmektedir (ICJ, 2009).

Cinsel yönelim, "bireyin kendi cinsiyetine, karşı cinsiyete veya birden fazla cinsiyete karşı sahip olduğu; cinsel çekicilik, yakınlık, istek, etkilenim ve derin duygusallık taşıma kapasitesi" olarak ifade edilmektedir (EU-Parliamentary Assembly, 2009). Günümüzde, tanımlanan birçok farklı cinsel yönelim türü vardır. Bunların en çok bilineni ve toplumlarca en çok kabul göreni heteroseksüelliktir. Heteroseksüellik, genel olarak bireyin sadece karşı cinse ilgi duyması olarak tanımlanabilmektedir. Daha açık bir ifade ile heteroseksüellik "bireyin, fiziksel ve duygusal olarak karşı cinsten olan bireylere duyduğu çekim" olarak ifade edilmektedir (LGBTQA+Resource Center, 2018). Heteroseksüel cinsel yönelimi normal kabul eden heteronormatif normların dışında kalan, yani kadın-erkek ikiliğine uymayan cinsel yönelimlerin hepsini kapsayan çatı terim "LGBT+" dir. Cinsel yönelime dayalı ayrımcılık genel olarak "yönelimleri nedeniyle LGBT+ bireylere yönelik olumsuz tutumlar" şeklinde tanımlanmaktadır. (Öner, 2015). LGBT+ bireylerin hak alanlarını genişletmek, korumak ve genel olarak insan haklarını evrensel olarak eşitlendirmek için uluslararası ve ulusal düzeyde çeşitli çalışmalar ve oluşumlar hayata geçirilmiş olsa da cinsel yönelim ayrımcılı̆̆ının engellenmesi için yeterli olamamıştır.

Örneğin, Avrupa'da Cinsel Yönelim ve Cinsiyet Kimliğine Dayalı Ayrımcılık adlı rapor (2011) ülkeden ülkeye farklılıklar göstermekle birlikte 47 ülkenin tümünde, homofobik ve transfobik tutumların var olduğu ve LGBT+ bireylere dönük kışkırtıcı ve saldırgan söylemlerin, varlığına işaret etmektedir. Türkiye'de gerçekleştirilen araştırmalarda da benzer tablo mevcuttur. "Biz'lik, 'Öteki'lik, Ötekileştirme ve Ayrımcılık: Kamuoyundaki Algılar ve Eğilimler" adlı araştırmanın sonuçlarına göre, herkesin çoğunluğunkinden farklı cinsel yönelimlerini serbestçe yaşayabilmesi hakkının tamamen kısıtlanabileceğini söyleyenlerin oranı \%53'tür (Yılmaz, 2010). Aynı araştırmada kimlerin kimliklerini rahatça açık edemeyeceğine dair soruya "homoseksüellik gibi başkalarından farklı cinsel yönelimleri olan" kişiler yanıtını verenlerin oranı ise \%72'dir. 2011 yılında gerçekleştirilen "Dünya Değerler Araştırması”"nın sonuçlarına göre ise Türkiye'de araştırmaya katılanların \%84'ü eşcinselleri komşu olarak istemediklerini belirtmişlerdir.

Tüm bunların arka planında; toplumsal normlar, önyargılar ve dinin etkili olduğunu söylemek mümkündür. Öyle ki, toplumsal düzen içerisinde cinsel yönelim ile ilgili belirli normlar mevcuttur. Yukarıda açıklanmaya çalışılıı̆ı üzere cinsel yönelimin farklı türleri olsa da sosyal düzen içerisinde en çok kabul gören heteroseksüelliktir. Heteroseksüellik her ne kadar kadın ve erkek arasındaki etkilenime vurgu yapıyor olsa da bundan öte bir anlam taşımaktadır çünkü toplumsal düzen içerisinde ataerki ile ilişkilendirilmektedir (Jackson ve Scott, 2012). Bununla birlikte, heteroseksüellerin nüfusun çoğunluğunu oluşturduğu ve "normal" olduğu kabul edilmektedir. LGBT+ bireylerin marjinalleştirilmelerine sebep olan toplumsal normlar da heteroseksist normlardır. Foucault'ya (2012: 100) göre, 18. yüzyıldan itibaren bilimin ilgi alanına giren beden ve cinsellik, bu dönemde, belirli normlarla ve kriterlerle şekillendirilmiş; kadın ve erkek ikiliği "normal" olarak kabul edilirken bunların dışında kalan bireyler "hasta" ya da "sapkın" olarak kategorize edilmişlerdir (Levine ve 
Leonard, 1984: 706). Sonuç olarak, bu ikilliğin doğal ve akla yatkın kabul edileceği düşüncesini oluşmuş ve bu "zorunlu heteroseksüellik" olarak tanımlanmıştır (Butler, 2010: 49; Jackson ve Scott, 2012: 148). "Heteronormativite" olarak tanımlanan bu sistem, beslediği normallik algısı üzerinden toplumsal bir beklentiye dönüşmekte ve bireyler üzerinde bir baskı aracı olarak kullanılarak varlığını sürdürülmektedir (Rudman ve Glick, 2008; Butler, 2009). Bu şekilde doğal kabul edilen kadın ve erkek ikiliği, toplum nezdinde meşruiyet kazanmakta ve bu toplumsal cinsiyet normlarına uymayan cinsiyet kimlikleri ise "marjinal" kabul edilmektedir (Butler, 2010: 50; Jackson ve Scott, 2012: 145). Öyle ki; bu ikilik, yani heteroseksüelliğin normalleştirilmesi üzerinden iktisadi yaşam, toplumsal yaşam ve aile yaşamı düzenlenmiştir (Connell, 1998; Butler, 2010; Foucault, 2012). Sonuçta bu rolleri destekleyen normların yeniden üretildiği heteroseksist bir toplumsal düzen içinde, heteroseksüellik dışında kalan cinsel yönelimler bu düzene tehdit oluşturur nitelikte kabul edilmekte ve bu bireylerin toplumdan izolasyonlarını ve dışlanmalarını da beraberinde getirmektedir (Kılıçaslan ve Akkuş, 2016: 41).

Toplumsal normların yanı sıra, cinsel yönelim ayrımcılığı üzerinde etkisi olan diğer faktör de dini kabullerdir. Din, yaşam biçimleri ve davranış eğilimleri yönünden birçok birey için belirleyici olmayı sürdürmektedir. Muhafazakâr ve geleneksel bakış açısı, hem LGBT+ bireylerin toplum içerisindeki yaşamlarını, hem de örgütlü faaliyetlerini kısıtlayabilmektedir. İslam dininin cinsel yönelim farklılıklarına olan bakış açısı toplum nezdinde heteronormatif değerlerin benimsenmesine ve LGBT+ bireylerin sosyal yaşamın birçok noktasında ön yargıya maruz kalmalarına neden olabilmektedir (KAOS GL, 2018). LGBT+ bireyler ile ilgili en çok karşılaşılan önyargılar, heteroseksist cinsel yönelim dışında kalan cinsel yönelimlerin hastalık olarak kabul edilmesi, cinsel yönelimin bir tercih olarak ele alınması, ahlaksızlıkla ilişkilendirilmesi sayılabilir (KAOS GL, 2018). Tüm bu nedenlerle, LGBT+ bireyler toplumun en çok ayrımcllığa uğrayan kesimlerinden birini oluşturmaktadır.

LGBT+ bireylerin çalışma yaşamında maruz kaldığı ayrımcı uygulamalar, iş sözleşmesinin başlangıcından feshine kadar olan süreçte çalışma yaşamının her aşamasını içine alacak şekilde çeşitlilik gösterebilmektedir. Levine ve Leonard (1984), çalışma yaşamında ayrımcılığı formel (resmi) ve informel (gayriresmi) ayrımcılık olarak sınıflandırmaktadırlar. Bu sınıflandırmaya göre, formel ayrımcılık; bireylerin cinsel yönelimlerinden dolayı işe alma, işten çıkarma, promosyonlar, yükselme, ücret artışları gibi kurumsal politika ve kararlarda ayrımcı tutumlara maruz kalmalarını ifade etmektedir. İnformel ayrımclık ise LGBT+ bireylerin örgütsel süreçlerin dışında iş ortamında cinsel taciz, sözlü taciz ve kişinin özel alanının ihlal edilmesiyle ortaya çıkan eylemlere maruz kalmaları olarak tanımlanmaktadır (Leonard ve Levine, 1984: 706). Burada sözü edilen ayrımcılık; LGBT+ bireylerin iş ortamında küçük düşürülmesi, kendileriyle alay edilmesi, hakarete ve hatta cinsel tacize uğramalarını içermektedir. Bununla birlikte, bu bireylerin cinsel yönelimlerinden dolayı, diğer insanlardan tepki görmekten kaçınmak amacıyla kendi kimliklerini gizli tutma ihtiyacı duymaları da bu ayrımcılığın bir parçası olarak kabul edilmektedir (Demirdizen vd., 2012: 314).

Ülkemizde, Anayasa'nın 10. maddesi tüm vatandaşların kanun önünde eşitliğini korurken, İş Kanunu'nun 5. maddesi ile de iş yerinde herkese eşit davranma ilkesi benimsenmektedir. Ancak, bu maddelerde "cinsel yönelim" ve "cinsiyet kimliği" ifadelerinin açıkça yer almadığı dikkat çekmektedir. İlgili maddelerde "cinsel yönelim" ve "cinsiyet kimliği" kavramlarının açıkça ifade edilmemiş olması LGBT+ örgütlerince eleştiri konusudur (ör: KAOS GL, 2015; SPoD, 2012).Bu durumun, LGBT+ bireylere yönelik ayrımcılığı önleme adına yetersiz kaldığı tartışılmaktadır (ör: Güner vd., 2011). Buradaki temel endişe, ilgili maddelerde yer alan "ve benzeri sebepler" ifadesinin cinsel yönelim ve cinsiyet kimliği kapsayacak şekilde kabul edilip edilmeyeceğinin belirsiz ve yoruma açık olmasıdır. Bu durum, söz konusu yasal düzenlemelerin uygulamada ayrımcı davranışları ne derece engelleyeceğini belirsiz kılmakta ve hatta Cesur-Kılıçaslan ve Akkuş (2016)'a göre cinsel yönelim ayrımcılığını yasaklamaya yönelik herhangi bir yasal tedbir oluşturmamaktadır. Bununla birlikte, pek çok kanunda yer alan utanç, terbiye, ahlak, vb. kavramların tanımlarının belirsiz olması, bunların LGBT+ bireylerin aleyhine yorumlanmasına ve bu bireylerin etiketlenerek çalışma yaşamında ayrımcı davranışlara maruz kalmalarına neden olabilmektedir. Örneğin, Devlet Memurları Kanunu'nun disiplin cezalarını düzenleyen 125. maddesi "devlet memuru vakarına yakışmayan tutum ve davranış" şeklinde bir ifade içermektedir. Türkiye'de Cinsel Yönelim ve Cinsiyet Kimliği Temelli İnsan Hakları İhlalleri İzleme Raporu (2012)'na göre bu madde 2012 yılında bir polis memurunun 
algılanan cinsiyet kimliğinden ötürü görevine son vermek amacıyla kullanılmıştır (SPoD, 2012). Bu noktada, LGBT+ bireylerin Türkiye'de yasal olarak en az korunan azınlık gruplarından biri olduğunu söylemek mümkündür.

Çalışma yaşamında cinsel yönelim ayrımcılığına ilişkin araştırmaların diğer ayrımcılık araştırmaları ile karşılaştırıldığında (örn. cinsiyet) sınırlı olduğu bilinmektedir. Bu kapsamdaki yazın 1980'lerde ABD merkezli araştırmalar ile başlamıştır (örn., Badgett,1995; Clain ve Leppel, 2001; Croteau, 1996; Griffin, 1992; Levine ve Leonard, 1984; Ragins, Singh ve Cornwell, 2007; Weichselbaumer, 2003). Örneğin, Badgett'ın (1995) çalışmasında, gey ve biseksüel erkeklerin meslek, eğitim, deneyim, yaş açısından benzer koşullara sahip heteroseksüel erkeklere göre \%11-27 daha az ücret aldığı tespit edilmiştir. Benzer şekilde lezbiyen kadınların, heteroseksüel kadınlara göre \%12-30 arasında daha az gelir elde ettiği bulgusuna ulaşılmıştır. Weichselbaumer (2003) ise çalışmasında, lezbiyenlerin iş görüşmesine çağrılmada, heteroseksüel kadınlara kıyasla \%12-13 daha fazla red aldıkları tespit etmiştir. Mishel (2016) tarafından yapılan daha güncel bir araştırmada ise lezbiyenlerin işe alım sürecini incelemek üzere, LGBT+ topluluklarında başkanlık yapma deneyimi eklenmiş kurgusal bir özgeçmiş yaratılarak heteroseksüel bir adaya ait yine kurgusal bir özgeçmiş ile birlikte 800 açık iş ilanına gönderilmiştir. Araştırma sonucunda, lezbiyen kadın adaya ait kurgusal özgeçmişe, \%30 oranında daha az geri dönüş olmuştur. Gey ve heteroseksüel erkekler üzerine yapılan benzer bir çalışmada Tilcsik (2011) gey adayların heteroseksüel erkek adaylara göre $\% 40$ daha az geri dönüş aldığını ortaya koymuştur.

Çalışma yaşamında cinsel yönelim ayrımcılığına ilişkin Avrupa temelli çalışmalarda da benzer sonuçlar izlenmektedir. Örneğin Drydakis (2009) tarafından Yunanistan'da gerçekleştirilen araştırmada, yukarıdaki çalışmayla benzer olarak adayın LGBT+ topluluklara üye olduğunu gösteren kurgusal bir özgeçmiş hazırlanmış ve işverenlerin işe alma karaları gözlemlenmiştir. Araştırma sonucunda geylerin heteroseksüel erkeklere göre daha az sayıda iş görüşmesi daveti aldıkları saptanmıştır. Baert (2017) tarafından Belçika'da gerçekleştirilen bir çalışmada ise katılımcılardan kendilerine gösterilen kurgusal özgeçmişleri değerlendirmeleri istenmiştir. Bu özgeçmişlerde adayların eşlerinin isimlerine yer verilmiştir. Belçika'da eşcinsel evliliğin yasal olmasından hareketle eşcinsel evlilik gerçekleştirmiş gibi gösterilen kurgusal adayların işe alım sürecinde heteroseksüel adaylara göre daha az olumlu dönüş aldığı tespit edilmiştir.

Türkiye'de LGBT bireylere yönelik yapılan çalışmalar sınırlı olmakla birlikte mevcut araştırmaların daha çok psikoloji ve tıp alanında yoğunlaştığı bilinmektedir (Demirdizen, Çınar ve Kesici, 2012). Bununla birlikte, son on yılda LGBT+ bireylerin sorunlarını konu edinen çalışmaların sayısında artış olduğu izlenmektedir (örn: Kutlu, 2009; Öztürk 2011; Yıldız, 2012; Demirdizen vd., 2012; Doğan, 2012 ve 2015; Öner, 2015; Göregenli ve Serdengeçti 2017). Demirdizen vd. (2012) tarafından gerçekleştirilen araştırmada, bireylerin cinsel yönelimlerinin çalışma arkadaşları tarafından öğrenilmesi ve diğerleriyle paylaşılmasına ilişkin duyulan kaygı raporlanmıştır. Bununla birlikte, bu katılımcıların ifşa olma sonucunda, iş arkadaşları tarafında alay edilme, tacize uğrama ve hatta işten kovulma kaygısı taşıdıkları da rapor edilmiştir. Doğan (2012) tarafından gerçekleştirilen başka bir araştırmada ise LGBT+ bireylerin işten çıkarılmaya zorlandıkları ancak bu duruma yönelik açıklamalarda işyerinin imajı nedeniyle cinsel yönelimden bahsedilmediği ve genellikle bireyin işin niteliğine uygun olmadığı gibi gerekçelerin öne sürüldüğü ortaya konmaktadır. Türkiye'de LGBT+ bireyler ile ilgili yapılan kapsamlı çalışmalardan biri olan Göçmen ve Yılmaz'ın (2016) çalışmasında ise heteroseksüel bireylerle kıyaslandığında, bu bireylerin iş açısından eşit haklara sahip olmadıkları ortaya konmuştur. Göregenli ve Serdengeçti (2017) tarafından gerçekleştirilen araştırmanın bulgularına göre, Türkiye'de özel bir şirkette çalışan 166 kişide cinsel yönelimleri konusunda işyerinde açık olabilenlerin oranı sadece \%17'dir. Aynı araştırmada, katılımcıların iş arama sürecinde işKUR ve özel istihdam bürolarını tercih etmekten kaçındıklarını ve çoğunlukla kariyer sitelerini ya da tanıdık tavsiyesi ile hareket ettikleri raporlanmıştır. Katıımcılar bu durumu, bu kanallara güven duymamaları ve "fişlenme" riskinin bulunması olarak gerekçelendirmişlerdir.

Her ne kadar Türk ayrımclık yazınında çalışma yaşamında cinsel yönelim ayrımcılı̆ını konu edinen çalışmaların sayısında son yıllarda artış gözlense de yabancı yazınla karşılaştıııldığında ülkemizde yukarıda bulgularına yer verilen bu çalışmaların sayıca daha az olduğu görülmektedir. Bu kapsamda, aşağıda, Türkçe literatüre bir katkı sağlaması amacıyla gerçekleştirilen bu araştırmanın tasarımına ilişkin bilgi verilmektedir. 


\section{Araştırma Tasarımı}

\subsection{Araştırmanın Amacı}

Bu araştırma, çalışma yaşamında ayrımcılığı konu edinen Türk literatüründe cinsiyet, yaş, engellilik gibi boyutlara kıyasla daha az çalışılan cinsel yönelim ayrımcılığına odaklanmaktadır. Bu kapsamda, bu çalışmada temel olarak LGBT+ bireylerin, çalışma yaşamında maruz kaldıkları ayrımcı davranışların neler olduğu araştırımaktadır. Buna ek olarak, çalışma kapsamında, LGBT+ bireylerin, çalışma ortamında karşılaştıkları ayrımcı davranışlara nasıl tepki verdikleri ve bu durumun onlara ne hissettirdiği hakkında fikir edinilmeye çalışılmaktadır. Ayrıca, LGBT+ bireylerin çalışma yaşamında ayrımcı davranışların nedenlerine ilişkin algılarının ortaya çıkarılması hedeflenmektedir. Çalışma yaşamında LGBT+ bireylerin karşılaştıkları ayrımcı davranışları inceleyen bu çalışmanın var olan literatüre katkı sağlaması ve bundan sonraki çalışmalara ışık tutması beklenmektedir.

\subsection{Araştırmanın Yöntemi}

Bu çalışma kapsamında araştırmanın amacına uygun olarak nitel araştırma metodolojisinden yararlanılmıştır. Bunun nedeni, anlamacı epistemolojiye dayanan nitel araştırmanın mantığında keşfetme ve anlama eyleminin yer almasıdır (Yıldırım ve Şimşek, 2000: 17). Bilindiği gibi, nitel araştırma, objektif, tek, maddi ve dışsal bir gerçekliğin var olduğu ontolojik sayıltısına dayanan pozitivist epistemolojinden farklı olarak, "neden?" ve "nasıl" sorularına cevap aramaktadır. Dolayısıyla da evrensel yasalar bulmak yerine, bir olguya belirli koşullar altında açıklık getirmeye ve anlamaya çalışmaktadır (Yıldııım ve şimşek, 2000: 31; Kuş, 2003: 5). Dolayısıyla nitel araştırma yöntem olarak araştırma probleminin yorumlayıcı bir yaklaşımla incelemesini içermekte ve araştırmaya "duygu" ve "doku" eklemektedir (Yıldırım ve Şimşek, 2008: 39-48).

Bu açıdan, araştırmanın amacı doğrultusunda LGBT+ bireylerin çalışma yaşamında karşılaştıkları ayrımcı davranışlar ve bunların arka planının anlamak amacıyla nitel bir araştırma tasarlanmıştır. Araştırma kapsamında veri toplama yöntemi olarak yarı yapılandırılmış görüşme tekniği tercih edilmiştir. Bilindiği gibi görüşme tekniği, bireylerin deneyimlerine, tutumlarına, görüşlerine ve duygularına ilişkin anlamlandırma sürecinde etkili bir teknik olarak kabul edilmektedir. Bu araştırmada belirli bir olayın ya da sürecin derinlemesine öğrenilmesini amaçlayan konu merkezli yarı-yapılandırılmış görüşme tekniği kullanılarak, önceden hazırlanan ve görüşmeyi yönlendiren bir kılavuz olarak tanımlanan görüşme protokolü (Yin,1984) üzerinden LGBT+ bireylerin çalışma yaşamında maruz kaldıkları ayrımcı davranışlar ile ilgili görüş ve düşüncelerinin ortaya çıkarılması amaçlanmıştır. Böylece, görüşmecilerin bakış açılarını öğrenmek amacıyla görüşme akışının esnekliğinin sağlanması söz konusu olurken aynı zamanda sistematik ve kurallara uygun görüşmeler gerçekleştirilmeye çalışılmıştır (Rubin ve Rubin, 1995).

Görüşme sorularının belirgin, açık ve kolay anlaşılabilir olmasına özen gösterilmiştir. Mümkün olduğunca "evet-hayır" cevaplı sorular yerine açık uçlu sorular tercih ediliştir. Sorularda görüşmecileri yönlendirebilecek herhangi bir durumdan özellikle kaçınılmıştır. Araştırmanın amacı ile uyumlu olarak görüşme protokolü "cinsel yöneliminizden dolayı Türkiye'de çalışma hayatında ne tür ayrımcı davranışlarla karşılaştınız; "Maruz kaldığınız ayrımcı davranışlar sizi nasıl etkilemektedir?" gibi sorulardan oluşmaktadır.

\subsection{Araştırmanın Örneklemi}

Araştırmanın örneklemi belirlenirken çalışma yaşamında LGBT+ bireylerin kendilerini açık edenlerin sayısının az olabileceği düşünülerek gönüllülük esasıyla hareket edilmiştir. Bu kapsamda, aktif şekilde çalışan ve araştırmaya gönüllü olarak katılmak isteyen LGBT+ bireylere ulaşabilmek için Türkiye'de faaliyet gösteren LGBT+ dernekleri ile iletişime geçilmiştir. Bu amaçla, KAOS GL, Pembe Hayat, Spod derneklerine araştırmanın amacını ve görüşme sorularını içeren bilgilendirici bir mail atılmış ve bu derneklere üye olan ve araştırmaya destek vermeyi kabul edenler üzerinden kartopu örneklemesi yöntemiyle örneklem genişletilmeye çalışılmıştır. Araştırmanın örneklemi, İstanbul ve Ankara illerinde yaşayan toplam 17 LGBT+ bireyden oluşmaktadır. Görüşmeler Şubat 2019 - Nisan 2019 tarihleri arasında gerçekleştirilmiştir. Görüşmecilerin izni alınarak ses kaydı yapılan görüşmelerin en kısası 32 dakika, en uzunu ise 59 dakika sürmüştür. Örneklemde LGBT bireylerin her birini temsilen görüşmeci bulunmasına özellikle dikkat edilmiştir. Tablo 1' de görüşmeci 
profili sunulmaktadır. Verinin kendisini tekrar etmeye başladığı noktada zaman kısıtı da göz önünde bulundurularak görüşmeler kesilmiştir.

Tablo 1. Görüşmeci Profili

\begin{tabular}{|l|l|l|l|c|}
\hline & Cinsel Yönelimi & Mesleği & $\begin{array}{l}\text { Kamu/Özel Sektör } \\
\text { Ayrımı }\end{array}$ & Yaşı \\
\hline G1 & Gey & iletişim sorumlusu & Özel Sektör & 32 \\
\hline G2 & Gey & Çevirmen & Özel Sektör & 26 \\
\hline G3 & Lezbiyen & Eğitmen & Özel Sektör & 27 \\
\hline G4 & Lezbiyen & Editör & Özel Sektör & 27 \\
\hline G5 & Gey & Çağrı Merkezi Sorumlusu & Özel Sektör & 30 \\
\hline G6 & Gey & Bilişim Uzmanı & Özel Sektör & 28 \\
\hline G7 & Transeksüel & Turizmci & Özel Sektör & 42 \\
\hline G8 & Lezbiyen & Öğretmen & Özel Sektör & 28 \\
\hline G9 & Gey & Satış Şefi & Özel Sektör & 31 \\
\hline G10 & Gey & Dış Ticaret Uzmanı & Özel Sektör & 32 \\
\hline G11 & Gey & Aş̧̧ı & Özel Sektör & 25 \\
\hline G12 & Lezbiyen & Ofis Asistanı & Özel Sektör & 28 \\
\hline G13 & Lezbiyen & Satış Danışmanı & Özel Sektör & 28 \\
\hline G14 & Gey & Tasarımc & Özel Sektör & 29 \\
\hline G15 & Gey & Mimar & Özel Sektör & 31 \\
\hline G16 & Transeksüel & Akademisyen & Kamu Sektörü & 32 \\
\hline G17 & Lezbiyen & Öğretmen & Kamu Sektörü & 36 \\
\hline
\end{tabular}

Analiz sürecinde öncelikle, görüşme kayıtları transkript edilmiş ve metinlerin çözümlemesi gerçekleştirilmiştir. Araştırmada veri analizi yönetimi olarak betimsel analiz ve içerik analizinden yararlanılmıştır. Tüm görüşmelerin transkript edilmesinin ardından elde edilen verilen içerik analizi yöntemiyle dört aşamada analiz edilmiştir. Bu aşamalar; verilerin kodlanması, kodlanan verilerden hareketle temaların belirlenmesi, belirlenen kod ve temaların düzenlenmesi ve son olarak bulguların yorumlanması şeklindedir (Yıldırım ve Şimşek, 2008: 228). Araştırma kapsamında her bir görüşmeciye G1, G2, G3 vb. şeklinde numara verilmiştir. Görüşmecilerin ifadeleri benzerlik kriteri esas alınarak makalenin iki yazarı tarafından ayrı ayrı kodlanmış, kodlar bir araya getirilerek bulgularının ana hatlarını meydana getiren temalar belirlenmiş ve kodlamalar karşılaştırılarak tutarlık oranı hesaplanmıştır. Araştırmanın kavramsal yapısının önceden açık bir biçimde belirlendiği durumlarda kullanılan betimsel analiz yöntemi çerçevesinde ise görüşmecilerin ifadelerini yansıtmak amacıyla doğrudan alıntılara yer verilmiş, ifadeler neden-sonuç ilişkileri çerçevesinde belirli bir örüntü yaratacak şekilde analiz edilmeye yorumlanmaya çalışılmıştır (Yıldırım ve Şimşek,2008: 224). Doğrudan alıntılar seçilirken çarpıcılık, açıklayıcılık ve çeşitlilik gibi kriterler dikkate alınmıştır.

Çalışmada araştırma bulgularının kendi içinde tutarlı ve anlamlı olmasını ifade eden içsel geçerliliği sağlamak amacıyla birkaç yöntem kullanıımıştır. Öncelikle, görüşmecilerin ifadeleri kodlanmış ve doğrudan alıntılarla kodlar desteklenmiştir. Temaları oluşturan kodların kendi içinde ve diğer temalarla olan tutarlığı test edilerek anlamlı bir bütün oluşturup oluşturmadığı kontrol edilmiştir. Araştırma sonuçlarının genellenebilir olmasını ifade eden dışsal geçerlilik ise araştırmanın doğası ve sonuçların yoruma açık olması nedeniyle nitel araştırmalarda oldukça güçtür ve böyle bir iddia da taşımamaktadır. Bununla birlikte, araştırma kapsamında görüşme protokolü hazırlanmasından, uygulama ve analiz aşamasına kadar tüm araştırma süreci açıklanmaya çalışılmıştır. Ayrıca, bulguların daha önce yapılan araştırmaların sonuçları ile uyumlu olup olmadığı izlenmiştir. Ancak elbette bu araştırmadan elde edilen veriler üzerinden yapılan yorumlar incelemeye tabi olan örmekler ile sınırlıdır. 


\section{Bulgular}

Araştırma tasarımı bölümünde belirtildiği üzere bu çalışmada temel olarak LGBT+ bireylerin çalışma yaşamında ayrımcı davranışları maruz kalıp kalmadıkları, eğer maruz kalıyorlar ise bu ayrımcı davranışların neler olduğu ortaya konmaya çalışılmıştır. Bununla birlikte, söz konusu ayrımcı davranışların sonuçlarını anlamaya dönük sorgulamalar yapılmıştır. Gerçekleştirilen analizinden temel olarak beş tema ortaya çıkmıştır. Bunlar; formel ayrımcılık, informel ayrımcılık, homofobi, bireysel başa çıkma mekanizmaları ve olumsuz etkiler şeklindedir. Aşağıda bir anlam bütünlüğü sağlanmaya çalışılarak bu temaları örnekleyen alıntılara yer verilmektedir.

\subsection{Formel Ayrımcilık}

Araştırma kapsamında elde edilen verilerden ortaya çıkan ilk bulgu, çalışma yaşamında LGBT+ bireylerin, Levine ve Leonard (1984)'ın kurumsal süreçlerde ayrımcılık olarak tanımladığı formel ayrımcılığa maruz kaldıkları olmuştur $(G 2, G 3, G 4, G 7, G 10, G 16, G 17)$. Yukarıda değinildiği üzere formel ayrımcılık; işe alınma, yükselme, işten çıkarılma gibi örgütsel süreçleri kapsamaktadır. Bu kapsamda LGBT+ bireylerin cinsel yönelimleri nedeniyle en çok işe alım süreçlerinde ayrımcı davranışlara maruz kaldıkları tespit edilmiştir. Bu bulguyu örnekleyen bir katılımcının konuyla ilgili görüşleri şu şekildedir:

"işe alım sürecinde şöyle bir ayrımcılığa uğradığımı düşünüyorum; kendi cinsiyet kodlarına uymayan bir dış görünüşe sahip olduğum için, o zamanlarda kısa saçlarım biraz daha androjen bir görüntü onlar için, yani çok 'feminen kadın'a uymadığı için bu noktada elendiğim çok oldu. Çünkü istenilen tüm şartları sağlarken, üniversite mezuniyetiyse mezuniyet, yabancı dilse yabancı dil, çok fazla rakibimin de olmadığı görüşmelerde sadece bu yüzden elendiğimi düşündüğüm çok oldu." (Lezbiyen, 27, Eğitmen)

Benzer bir örnekte, yine işe alım sürecinde bireylerin cinsel yönelim farklııklarının sorgulandığına ve imalı şekillerde irdelendiğine dikkat çekilmektedir. Bir katılımcı, yaşadığı tecrübeyi şu şekilde paylaşmaktadır:

"Bundan iki önceki işimde görüşmeye gittiğimde patron askere gidip gitmediğimi sormuştu, ben de henüz gitmedim demiştim. 'Neden gitmedin, bir sorunun mu var?' gibi bir cümleyle karşılamıştı beni kendisi. Ben de 'hayır kesinlikle bir sorunum yok, sadece henüz gitmedim' dedim. Sonra başka sorular sormaya başladı; 'Kız arkadaşın var mı? Eşin var mı? Karın var mı?' Ben de sadece gülerek geçiştirmeye çalışmıştım ama orada anlıyorsun. Sen birazdan bir ayrımcılığa uğrayacaksın!" (Gay, 26, Çevirmen)

Yine benzer bir örnekte, işe alım sürecinde bireylerin görünüşlerinden hareketle önyargılı tutumlara maruz kaldıkları gözlenmektedir. Turizm sektöründe çalıştığı döneme ilişkin deneyimini aktaran bir katılımcının ifadeleri aşağıdaki gibidir:

"Temelinde senin görünür olman, ben buradayım demen, bazı kıyafetlerinde davranışlarında bir farklılık gördükleri anda sana karşı önyargılı davranıp senin gibi bir insanla çalışmak istemiyorlar, senin yaptığın işin onlar için hiçbir önemi yok çünkü, açık bir şekilde istemiyorlar görmek istemiyorlar." (Transeksüel, 42, Turizmci)

Formel ayrımcılık içinde kabul edilebilecek bir diğer bulgu ise LGBT+ bireylerin çalışma yaşamında yükselme/terfii süreçlerine ilişkindir. Bu bulguyu örnekleyen bir katılımcı deneyimini aşağıdaki şekilde ifade etmektedir:

"Bir önceki işimde terfi almayı bekliyordum. Fakat performans değerlendirmelerden bir tanesinde insan kaynakları ile bir tartışmamız oldu. Bu tartışmanın sebebi de benim liderlik vasfının olmadığı ile ilgiliydi. Niye yok diye önce anlamaya çalıştım sonra fark ettim ki kafalarındaki liderlik vasfı erkek olmakla, heteroseksüel bir erkek olmakla alakalı, masaya yumruğunu vurdumu inleten ses çıkartan otoriter bir figürden bahsediyorlar. Yani orada görmek istedikleri şey bende yoktu yani cinsel yönelimim bunu sağlamıyordu onlar için. Görüşmemizde neden liderlik vasfımın olmadığını sorduğumda 'sende sağlam bir duruş yok' deyip bana bir tane fotoğraf gösterdi. Fotoğrafta erkek bir futbolcu seviniyordu. 'Işte duruş böyle olmalıdır' dedi. Bir süre sonra bu işten ayrıldım." (Gey, 32, Dış Ticaret Uzmanı) 
Formel ayrımcılık içinde değerlendirilebilecek diğer bir konu ise LGBT+ bireylerin cinsel yönelimleri nedeniyle işten çıkartılabildikleridir. Örneğin, bir katılımcı öğretmen olarak çalıştığı dönemde cinsel yönelimini açıkladıktan sonraki işten çıkarılma deneyimini şu şekilde paylaşmaktadır:

"Iingilizce öğretmeni olarak çalıştığım zamanlarda çok uzunca bir süre uğradığımı düşünüyorum. Etrafım nişanlı, evlenmek üzere olan, hamile olan veya hamileliğin başında olan insanlarla doluydu ve erkek arkadaşın yok mu diye sürekli bir baskı özel hayatıma dair sürekli bir irdeleme vardı. Artık bu sorulardan çok yılmaya başladığım bir zamanda 'ne zaman evleneceksin' sorusu geldiğinde 'Türkiye'de yasallaştığında [eşcinsel evlilik] evlenmeyi düşünüyorum' cevabını verdikten sonra işime son verildi." (Lezbiyen, 27, Eğitmen)

Yukarıdaki veriler incelendiğinde, özellikle işe alım, işten çıkarılma ve yükselme konularında LGBT+ bireylerin formel ayrımcılık olarak kabul edilebilecek ayrımcı davranışlara maruz kalmış olduklarını söylemek mümkündür. Bununla birlikte, katılımcılar LGBT+ bireylerin formel ayrımcılık yaşamalarının en önemli nedenlerinin biri olarak yasal düzenlemelerin beklenilen düzeyde olmaması vurgulamışlardır. Literatürde de belirtildiği üzere, Türkiye'de LGBT+ bireyleri korumaya yönelik düzenlemelerin yetersiz olduğu tartışılmaktadır. Yayımcılık sektöründe çalışan bir katııımının bu duruma ilişkin görüşleri aşağıdaki gibidir:

"Türkiye'de kanuna geçmiş henüz bir şey yok elle tutulur, gözle görülür ya da ne bileyim en ufak bir olay olduğu zaman bu olayı savunacak bir kâğıt üzerinde bir anlaşma yok. En büyük eksiklik bu, bu açıdan bir sıkıntımız var. Söylemlerde kalıyoruz şöyle böyle destekliyorum falan diye ama kâğıt üzerinde netleştirilmiş bir şey yok... Şu an hiçbir şekilde haklarımız olmadığı için hiçbir şekilde hiçbir şey yapamadığımız için tamamen üçüncü sınıf muamelesi görüyoruz tamamen veya arka planda kalıyoruz yani görünür olmuyor ama Avrupa'da bir kanun var yani sen hangi kimliğe sahip olursan ol eğer tacize, tecavüze veya şiddete uğruyorsan ben seni korumakla yükümlüyüm diyebiliyor." (Lezbiyen, 27, Editör)

Yukarıdaki ifadelerin yanında, görüşmecilerden elde edilen dikkat çeken bir bulgu formel ayrımcılığın şirketin kurumsallaşma düzeyine ve yerel/uluslararası alanda faaliyet göstermesine göre farklılık arz edebileceğine işaret etmektedir. Türkiye'de faaliyet gösteren global bir şirkette çalışan bir katılımcı bu noktayı şu şekilde açıklamaktadır:

"Çalıştığım firma global bir firma ve burada bu ayrımcılığın yaptırımları gerçekten çok ciddi boyutlarda. İş hakkı feshine kadar gidebilecek yaptırımları olduğu için kariyer, maaş iyileştirme vs. bu gibi durumlarda hiçbir şekilde yaşamadım bunu[ayrımcılığı]. Çünkü yaşamam durumunda başına gelecekleri şirket bildiği için, yaptırımlarımın çok büyük bir ölçüde olduğunu bildikleri için bana bunu hiçbir şekilde yaşatmadılar". (Gey, 32, iletişim Sorumlusu)

Benzer şekilde, bir diğer katıımcı da aynı noktayı şöyle vurgulamaktadır.

"Şu an çalıştığım yer kurumsal bir yer. Sadece eşcinsellikten ziyade, yönelimden ziyade etnik köken vs. gibi şeylere de dikkat eden bir kurum. Dolayısıyla kurumsal ve uluslararası bir şirket olması nedeniyle bence bu konuda özen gösteriyorlar." (Gey, 30, Çağrı Merkezi Sorumlusu)

Bu bulgu, uluslararası şirketlerin çeşitlilik ve kapsayıcılığa ilişkin destekleyici yaklaşımları göz önünde bulundurulduğunda beklenen bir durumdur. Öyle ki, günümüzde pek çok uluslararası şirket ayrımcılığa karşı son derece hassas davranmakta, çeşitlilik ve kapsayıcılık temelinde projeler yürütmekte ve çeşitliliği örgütsel değerlerinin arasında kabul ettiğini deklare etmektedir. Bu durumu örnekleyen bir katıımcının aktardıkları şu şekildedir:

"Şu an çalıştığım şirket bu konuda iyi bir örnek. Ayrımcılık yapılmayacağını belirtilen iki tarafı bir anlaşma imzaladım. Ben de cinsel yönelime dair ayrımcılık yapılmasını engelleyen bir maddeyi ilk kez burada gördüm." (Lezbiyen, 28, Ofis Asistanı)

Katılımcıların yukarıdaki ifadelerinden anlaşıldığı üzere Türk çalışma yaşamında formel ayrımcılığın açık ve doğrudan şekilde deneyimlendiği gözlenmektedir. Bununla birlikte, işten çıkarılma ya da işe alınmama gibi durumları açıkça yaşamamış olan LGBT+ bireylerin de her an bu ve buna benzer durumların 
gerçekleşebileceği kaygısını taşıdıkları görülmektedir. Devlet üniversitesinde çalışan bir akademisyen günümüzdeki politik ortamın da etkisiyle memuriyet hayatının sonlanmasından kaygı duyduğunu şu şekilde ifade etmektedir;

"Çeşitli anlamlarda kendimi kısıtlanmış hissediyorum. Özellikle de psikolojik olarak bir baskı altında hissediyorum çünkü istediğim gibi giyinip, istediğim gibi davranıp, istediğim gibi konuşmak içimden geldiği gibi kolay olmuyor ve özellikle bu hem ülkedeki politik yapı hem muhafazakar yapı sebebiyle hem de üniversitedeki ilişkiler idari ilişkiler hem de iş sebebiyle çeşitli yasalar falan hani o sebeple bazı açılardan kendimi baskı altında hissediyorum. Bu baskı genel anlamda idare, dekanlık, üniversite yönetimi bunlarla alakalı aslında, iş kaybıyla ilgili kaygı, ahlaka karşı yasalar gibi bazı temelde memuriyete bağlı yasalar olduğu için çekinmeme sebep oluyor pek çok açıdan". (Transseksüel, 32, Akademisyen)

\subsection{Informel Ayrımcilık}

Araştırma kapsamında tespit edilen diğer bir bulgu ise LGBT+ bireylerin, Leonard ve Levine (1984: 706)'ın sınıflandırmasına göre informel ayrımcılık olarak tanımlanan kurumsal politikaları içermeyen fakat üstler, çalışma arkadaşları vb. tarafından küçümseme, sözlü taciz, kişinin özel alanının ihlal edilmesi gibi eylemlere maruz kaldıklarıdır (G1, G2, G3, G4, G6, G9, G10, G15). Örneğin, bir katılımcı çalışma ortamı içinde rencide edildiği bir deneyimini şu sözler ile paylaşmaktadır:

"Bundan yaklaşık 2-3 ay önce benzer bir durumu farklı bir firmada yaşadım. Bir yönetici, $X$ projeden eski personellerim ve beni tanıyan insanlar ve tanımadığım birçok kişinin olduğu bir alanda beni sorguya çeker gibi şeyler sormaya başladı aksini iddia etmeme rağmen yargılayıcı şeyler, hakaret boyutunda konuşmaya başladı. Ben sakinliğimi korumaya çalıştım. Arkasını döndü tam giderken sen önce bir cinsel kimliğini belirle gibi bir ithamda bulundu. Döndüm, yutkundum. Baş başayken bu şeyi yapmış olsaydı belki daha çabuk atlatabilirdim ama dediğim gibi tanıyan insanlar var, üst yönetimden bir insan orada ve bana söylediği şey gerçekten çok ağır ve benim tamamen mahremimle alakalı olan bir şey". (Gey, 32, iletişim Sorumlusu)

Benzer şekilde başka bir katılımcı da rencide edici söylemlerin varlığını destekleyici aşağıdaki örneği paylaşmıştır:

"Rahatsız edici bakışları, laf sokmaları olabildiğince iğneleyici şekilde olabiliyor. Daha çok '[küfürlü ifade]' kullanıyorlar bizim için ve bunu nefretle ve öfkeyle kullandıkları için inanılmaz derecede sinirlendirici. Yani hem kadınsın, hem lezbiyensin iki kat ayrımcılığa uğruyorsun."(Lezbiyen, 27,Editör)

Bilişim sektöründe çalışan gey bir katılımcı ise örtük ayrımcı davranışlara sıkça rastlandığına dikkat çekmektedir. Katılımcının bu konuyla ilgili görüşleri şu şekildedir;

"Iş̧ yerinin yönetimsel taraflarında uğradığımı düşünmüyorum, daha çok arkadaş ortamında. Çünkü kimse doğrudan bir söylemde bulunmasa bile samimiyetle birlikte yapılan espriler kırıcı olabiliyor. Üstü kapalı şekilde bile olsa hissettirilebiliyor bu durum. Bir de günlük dilde bazen eşcinselliğe yönelik hoş olmayan küfür benzeri kelimeler duyuyoruz." (Gey, 28, Bilişim Uzmanı)

Diğer bir katılımcı da benzer şekilde iş arkadaşlarının rahatsızlık verici tepkilerinden söz etmiştir.

"En ufak kötü bir bakış bile hissettirebiliyor kendisini veya en ufak bir söylem ya da arkadan el kol hareketi yapmak, sonuçta çalıştığımız yer her taraf cam, ayna vs. tarzı şeyler o yüzden arkandaki insanları görebiliyorsun, ne yaptığını ne ettiğini... En basiti geçen ay yeni başlayan bir projede eğitim alan birkaç tane adam ben önde yürüyorum onlar arkadalar operasyon kapısına doğru yaklaştım arkamdan böyle el kol hareketi vs. yapmaya başladılar döndüm baktım kafasını direkt yere eğdi çekti gitti. Hani bu bile gerçekten 2-3 gün etkisinden kurtulamadığım bir hareket oldu". (Gey, 32, iletişim Sorumlusu) 
Bununla birlikte katılımcılar, kendileriyle diğerlerine kıyasla daha yüzeysel ilişkiler kurulduğunu, sosyal süreçlerden de dışlandıklarını ve aşağılanmaya maruz kaldıklarını belirtmektedirler. Örneğin bir katılımcı bu durumu şu şekilde açıklamaktadır:

"Ayrımcılığı şurada hissedebiliyorsun evet belki iş konusunda değil ama muhabbet anlamına girdiğinde X bir yönetici. Mesela sen ve ben aynı yöneticiye bağlıyız. Seninle sohbet ederken gözlerinin içi parlıyor. Daha böyle candan, yürekten sohbet ederken gözler bana döndügüunde 'Nasılsın? lyi misin? Tamam, iyiyim, güle güle'ye bağlayabiliyorlar olayı. Gayet yüzeysel. Hani pisliğe bakar gibi baktığını hissettirebiliyor. Senin bir vebalıymışsın gibi bakışları var". (Gey, 32, Dış Ticaret Uzmanı)

\subsection{Homofobi}

Verilerden elde edilen diğer bir bulgu da Türk çalışma ortamında homofobik söylemin oldukça yaygın olduğuna ilişkindir (G1, G3, G4, G7, G9, G11, G16). Türk çalışma ortamı ile ilgili bu tespiti yapan ilk çalışmalardan olan Öztürk (2011)'ün çalışmasının üzerinden uzunca bir süre geçmiş olmasına rağmen homofobik söylemin varlığını koruyor olması dikkat çekici bir bulgudur. Örneğin bir katılımcı bu konuda görüşünü şu şekilde açıklamaktadır:

"Cinsel yönelimimi söylemediğim bir yayınevinde çalışmıştım. Çalıştığım yayınevinde o zaman istanbul'da Onur Yürüyüşü olacaktı ve onun hazırlıkları vardı. Yayınevi sahibi Onur Haftasıyla ilgili bir espri yaptı ve çok kötüydü. Homofobik bir espiriydi ve ben buna karşı çıktım. Sonra bunun üzerinden tartıştık ve adam saygı duymadığı gibi nefret söylemlerini olabildiğince devam ettirdi ve bunun üzerine dedim ben lezbiyenim ve destekliyorum böyle olmaya devam edeceğim dedim. Bundan sonra aramıza bir soğukluk girdikten sonra ben çok daha fazla duramayacağımı anlayıp çıktım”. (Lezbiyen, 27, Editör)

Çalışma ortamında homofobinin varlığını gösteren bir başka örnek ise nefret söylemine dikkat çekmektedir. Öyle ki bahsedilen bu homofobik ortam, kişinin cinsel kimliğini açıklamasını engelleyici bir durum teşkil etmiştir. Katılımcı yaşadıklarını şu şekilde aktarmıştır:

"Hem freelance çalışı̆̆ım zaman hem bir ofis ortamında hem okulda belli bir grupta sürekli homofobik söylemler, yani bu benim mesela out olmamı [cinsel yönelimi açılamak] engelleyen bir durumdu çünkü inanılmaz kötü homofobik ve transfobik yorumlarda bulunuluyordu. Örneğin trans bir arkadaşım beni almaya geldiğinde ya da belirgin bir şekilde eşcinsel bir arkadaşım geldiğinde, 'Allah korusun biz de öyle olabilirdik, çocuğum eşcinsel olsaydı onu evden atardım' gibi yorumlar ve nefret söylemi çok fazla yaşadım içinde bulunduğum ortamlarda". (Lezbiyen, 27, Eğitmen)

Bununla birlikte, Türk toplumunun ataerkil yapısı, toplumsal normlar ve din de homofobik ve ayrımcı davranışlarla ilgili olarak vurgulanan diğer bir noktadır. Katılımcılar, cinsel yönelim farklılıklarının İslam dini içinde sıcak karşılanmamasının ayrımcı tutuları ve homofobik söylemi güçlendirdiğini düşünmektedirler. Örneğin bir katılımcı aşağıdaki görüşleri paylaşmaktadır:

"Kültürel aslında, yani Orta Doğu kültürü ile alakalı bence. Dinin de burada çok ciddi bir yüzdesi var çünkü bu kültürün büyük paydasını din oluşturuyor bence. Bunun çok yanlış olduğu, günah olduğu düşüncesine inanılıyor. Insanlar bunun günah olduğunu, bir sınav olduğunu, nefsimizi tutmamızı gerektiğini ve nefsin yenilmesini düşündükleri için her türlü saldırıy; fiziksel, sözel psikolojik kendilerinde hak görüyorlar." (Gey, 31, Satış Şefi)

Bunlara ek olarak, toplumun bilinçsizliği ve bu durumun "açıklanamaz" olarak kabul edilmesi de LGBT+ bireylerin işyerinde ayrımcı davranışlara maruz kalmalarının nedenlerinden biri olarak dikkat çekmektedir. Örneğin bir katılımcı bu konuya şu şekilde açıklık getirmiştir:

"Genelde şunu söylerler herhangi bir transı çalıştırırsam müşteri gelmez, hatta dinen bakacak olursak bereketi kaçar diyen insanlar bile var. Kısacası korkuyorlar, insanlara açıklama yapmak zorunda hissediyorlar kendilerini, normal biri varken neden seni çalıştırayım ki diyor aslında." (42,Transeksüel,Turizmci) 
Katılımcıların değindiği diğer bir nokta ise son döneme hâkim olan politik söylemdir. Yayımcılık sektöründe editör olarak çalışan bir katılımcı, yayım evinin politik söyleme yakın durmayı tercih ederek LGBT+ bireylere ve onlarla ilgili konulara mesafeli olduklarının altını çizmektedir.

"Belli bir kesim var ve o kesim kesinlikle LGBT'Yi desteklemiyor, devlet yanlısı, yaptığı işlerin satılması için, okurlardan da çok korkuyorlar. LGBT'yi desteklemeyen kesim çok kalabalık olduğu için, çok fazla satış olduğu için onu kaybetmemek için geri planda her şeyi yapmaya hazırlar. LGBT+ kitapları çıkartmaya dönük bir proje teklif ettiğimde 'ne LGBTsi?' tarzında söylemlerde bulundular. Ciddi anlamda dışarıdan bakıldığı zaman demokratik insanlar olarak görülüyorlar ama ellerinden gelse öldürecekler, öldürmüyorlar da tabi..." (Lezbiyen, 27, Editör).

\subsection{Bireysel Başa Çıkma Mekanizmaları}

Araştırmadan elde edilen verilerden ortaya çıkan diğer bir tema ise LGBT+ bireylerin çalışma yaşamında gerek formel gerek informel, gerek açık gerekse örtük ayrımcılık davranışları ile mücadele etme yöntemlerine ilişkin fikir vermektedir. Bulgular incelendiğinde, görüşmecilerin ayrımclıkla ve homofobik söylem ile başa çıkabilmek için bireysel olarak çeşitli mekanizmalar kullandıkları görülmektedir. Bu kapsamda, LGBT+ bireylerin çalışma ortamındaki homofobik söylemlere ve ayrımcı davranışlara maruz kalmamak adına çoğunlukla cinsel yönelimlerini gizleme eğiliminde oldukları anlaşılmaktadır (G1, G4, G8, G11, G16, G17). Bir katııımcı bu durumu şu şekilde açıklamaktadır:

"Çalışma hayatımda cinsel yönelimimi belirtemiyorum, birçok insan bundan habersiz. Sadece güvendiğim 2-3 arkadaşıma bundan bahsettim. Örneğin eski işimde arkadaşım patronumdu, kendisi açık görüşlü bir insandı, bu durumdan dolayı burada sıkıntı çekmeyeceğimi söyledi fakat diğer iş arkadaşlarım işe bu durumu paylaşmamam gerektiğini söyledi. Yani çoğu insan saklamak zorunda maalesef, ben mesela yarın bir gün KPSS sınavına girip atanmak istiyorum ama sosyal hesaplarımın ortaya çıkması ve bu nedenlerden dolayı atanamamak en büyük korkularımdan." (Lezbiyen, 28, Öğretmen)

Illetişim sektöründe çalışan bir katılımcı ise bu konudaki görüşlerini şu şekilde açıklamaktadır:

"LGBT+ bireyler gerek ailesinden dolayı gerekse çevresinde ki insanların dar görüşünden dolayı çok fazla gizlenme gereği duyuyorlar. Sebebi de ne yazık ki iş yerindeki kötü bakışlar, kötü zihniyet, aşağılanma duygusu... Gününün büyük bir çoğunluğunu geçirdiğin alanda insanların sana kötü bir şekilde bakmasını engelleyebilmek için bu maskeyi ister istemez takabiliyoruz." (Gey, 32, iletişim Sorumlusu)

Bununla birlikte nadiren LGBT+ bireyler, ayrımcılık ile baş etmek için homofobik ortama tepki olarak cinsel yönelimlerini açık etme yolunu da tercih etmektedirler. Hatta katılımcıların ifadelerinden bu durumu diğerlerine rahatsızık verecek boyuta taşımaya çalışarak dikkat çekmek istedikleri anlaşılmaktadır. Bir katılımcı bu tercihini şu şekilde gerekçelendirmektedir.

"Genellikle espri arasında 'kadınlardan hoşlanıyorum' ya da 'kadınları çok seviyorum' diyorum. Mesela yayınevine yeni bir tane kadın geldiği zaman 'kadın çok güzelmiş ya acaba bir numarasını alabilir miyim?' tarzında insanları rahatsız edecek boyutta söylüyorum ya da bazen çantamda olsun bazen giydiğim gömleğimin ucunda gökkuşağı broşu oluyor, iki kadın yan yana oluyor ya da kalp oluyor. Tarafımı belli etmeye çalışıyorum." (Lezbiyen, 27, Editör)

\subsection{Psikolojik Etkiler}

Araştırmalardan ortaya çıkan son tema ise ayrımcı davranışların LGBT+ bireyler üzerinde yarattığı etkiler ile ilgilidir. Görüşmeciler çalışma yaşamında maruz kaldıkları ayrımcı davranışların kendilerini psikolojik olarak olumsuz şekilde etkilediğini ifade etmektedirler (G1, G2, G3, G5, G7, G9, G11, G16, G17). Bir katılımcının konuyla ilgili görüşleri şu şekildedir:

"Çalışmanın dışında aslında her yerde cinsiyet ayrımcılığı çok fazla ama iş yerinde daha çok sarsabiliyor insanı. Çünkü günümüzün büyük bir çoğunluğunu iş yerinde geçiriyoruz, hani ailemizi 
göremediğimiz kadar aslında iş yerindeki insanları görüyoruz. O yüzden buradaki ayrımcılık daha çok sarsabiliyor, uzun bir süre etkisinden kurtulamadığım şeyler yaşadım. Senelerdir, kendimi bildim bileli daha doğrusu farkımın farkındayım ve ailesi tarafından bile kabul edilmiş bir insan olmama rağmen bu galiba büyük bir travma ve hiç birimiz atlatamayacağız bu travmayı ne yazık ki. Hani karahindiba gibi en ufak bir rüzgarda bile savrulup gidebiliyoruz, kırılabiliyoruz. Yani en ufak bir söz bile bizi gerçekten çok çok hızı bir şekilde sarsabiliyor. Her karşılaştığımızda da aynı etkide sarsmaya devam edecek". (Gey, 32, iletişim Sorumlusu)

Örneğin bir katılımcı mahalle baskısı olarak değerlendirilebilecek baskı nedeniyle ailesi tarafından yaşadığı şehirden ayrılmaya zorlandığını şu şekilde açıklamaktadır:

"Ankara'dan Istanbul'a gitme nedenim bazı davranışlarımın feminenleşmesinden dolayı annemler beni ablam ve eniştemin yanına çalışmam için göndermişlerdi. Burada etraf, konu komşu ne der mantığı ile aslında bir nevi sürgüne zorlandım. Tabii kendini saklamak zorundasın, iş yerinde mahallende daha dikkatli davranmalısın yoksa hakarete, şiddete, cinsel tacize uğrarsın. Benim için ailem tarafından zorla göçe zorlanmaktı bu. Çok zor tabii, kendi içimden niye bunu yaparlar ki derdim. Kısacası bir yama gibiydim." (Transeksüel, 42, Turizmci)

Katılımcılar ayrıca, bireysel olarak verilen bu mücadelenin yıldırıcı olduğu da vurgulanmaktadırlar. Bir katılımcı bu durumu şu sözlerle açıklamaktadır:

"Açıkçası ama çok uzun senelerdir bunun mücadelesini vermek belli bir noktada yorgunluk da getiriyor." (Lezbiyen, 27, Eğitmen)

\section{Sonuç}

Türkçe literatürde görece az çalışan bir konu olan çalışma yaşamında cinsel yönelim ayrımcılığına odaklanan bu araştırmanın bulguları açık bir şekilde LGBT+ bireylerin Türk çalışma yaşamında ayrımcılığa maruz kaldıklarını göstermektedir. Nitel araştırma metodolojisine dayanarak kartopu örneklemesi yöntemi ile ulaşılan 17 LGBT+ birey ile gerçekleştirilen yarı yapılandırılmış görüşmelerden ortaya çıkan ilk bulgu, LGBT+ bireylerin çalışma yaşamında formel ayrımcılığa maruz kaldıklarıdır. Daha açık bir ifade ile LGBT+ bireyler cinsel yönelimleri nedeniyle örgütsel süreçlerde ön yargıya maruz kalmakta; işe alınmama, yükseltilmeme ve cinsel yönelimleri açığa çıktığında işten atılma gibi problemler ile karşı karşıya kalmaktadırlar.

Bununla birlikte, araştırmanın bulguları LGBT+ bireylerin çalışma yaşamında informel ayrımcılıkla da karşılaştıklarını göstermektedir. Öyle ki, görüşmeciler çalışma ortamında imalı konuşma, küçümsenme, hakaret, dalga geçilme, taciz gibi istenmeyen durumlara maruz kaldıklarını belirtmektedirler. Görüşmeciler ayrıca bu durumun kendilerini psikolojik olarak olumsuz etkilediğini; kırdığını, üzdüğünü ve hatta travmaya sebep olduğunu vurgulamaktadırlar. Bununda dışında homofobik söylemler de çalışma yaşamındaki LGBT+ bireyleri en çok rahatsız eden konulardan biridir. Öyle ki, cinsel yönelimleri açık olmasa dahi bu gibi söylemler LGBT+ bireyleri bulundukları sosyal ortamda konforsuz hissetmelerine sebep olmaktadır. Bu durumun bir sonucu olarak da bu bireyler çalıştıkları şirketlerine ve iş arkadaşlarına karşı bir aidiyet geliştirememektedirler.

Araştırmanın bulguları ayrıca, LGBT+ bireylerin çalışma yaşamında kendini lanse ediş biçimlerine ve söz konusu ayrımcı davranışlarla nasıl mücadele ettiklerine ilişkin de ipucu vermektedir. Örneğin, çoğu görüşmeci, ayrımcı davranışlara maruz kalmamak için cinsel yönelimini çalışma ortamında gizleme yolunu tercih ettiklerini ifade ederken, az sayıdaki görüşmeci ise cinsel yönelimlerini özellikle açık ettiklerini ve hatta vurguladıklarını belirtmiştir. Bu bulgu LGBT+ bireylerin baskılara karşı kendi varlıklarını diğerlerine kabul ettirmeye çalışmaları başka bir deyişle "ses çıkarma çabası" olarak yorumlanabilir.

Son dönemde LGBT+ bireylerin görünürlüklerinde bir artış olduğu gözlenmekle birlikte halen ülkemizde cinsel yönelim farklılıklarına ilişkin bir ön yargının olduğu ve bu bireylerin genel olarak toplumsal hayatta spesifik olarak da çalışma yaşamında "kabul edilir" hale geldiklerini söylemek zordur. Araştırma sonuçları göstermektedir ki LGBT+ bireyler çalışma hayatında pek çok alanda hak ihlaline uğramakla birlikte kendilerini göre daha rahat hissettikleri çalışma alanlarına yönelmişlerdir. Bu açıdan örneklemi oluşturan 17 görüşmecinin sadece ikisinin kamu sektöründe çalışıor olması dikkat çekici bir bulgudur. 
Sonuç olarak, farklı sektörlerde, farklı yönetsel düzeylerde, cinsel kimliğini açık eden ve etmeyen LGBT+ bireylerden oluşan bir örneklem üzerinden Türk çalışma yaşamında cinsel yönelim ayrımcılığına odaklanan bu çalışma, LGBT+ bireylerin çalışma ortamında gerek örgütsel süreçlerde gerekse sosyal süreçlerde ayrımcılığa maruz kaldıklarını göstermektedir. Çalışmanın bulguları ayrıca Türk çalışma ortamında homofobinin var olduğuna, LGBT+ bireylerin ayrımcılık ve homofobi ile mücadele etmek için bireysel bir takım başa çıkma mekanizmaları kullandıklarını ancak tüm bu süreçlerden olumsuz etkilendiklerini göstermektedir. Ülkemizde görece az çalışlan bir konuyu ele alan bu çalışmanın, öncelikle LGBT+ bireylerin cinsel yönelimlerinden dolayı çalışma yaşamında maruz kaldıkları ayrımcılığa ilişkin farkındalığı pekiştirmeye katkı sağlaması umulmaktadır. Bununla birlikte bu çalışma, toplumsal normlara istinaden "anormal” kabul edilen cinsel yönelim farklııkları hakkında bilgi verilmesi ve ön yargıların kırımasına destek olmayı amaçlamaktadır.

\section{Beyan ve Açıklamalar (Disclosure Statements)}

1. Bu çalışmanın yazarları, araştırma ve yayın etiği ilkelerine uyduklarını kabul etmektedirler (The authors of this article are admitted that they complied with the principles of research and publication ethics).

2. Yazarlar tarafından herhangi bir çıkar çatışması beyan edilmemiştir (No potential conflict of interest was reported by the authors).

3. Bu çalışma, intihal tarama programı kullanılarak intihal taramasından geçirilmiştir (This article was screened for potential plagiarism using a plagiarism screening program).

\section{Kaynaklar}

Badgett, L. (1995). The wage effects of sexual orientation discrimination. Industrial \& Labor Relations Review, 48(4), 726-739.

Baert, S. (2017). Hiring a gay man, taking a risk? A lab experiment on employment discrimination and risk aversion. Journal of Homosexuality, 65(8), 1015-1031.

Butler, J. (2009). Toplumsal cinsiyet düzenlemeleri. Cogito: Feminizm, 58, 73-91.

Butler, J. (2010). Cinsiyet belası (Çev. B. Ertür). İstanbul: Metis Yayıncılık.

Clain, S. H., \& Leppel, K. (2001). An investigation into sexual orientation discrimination as an explanation for wage differences. Applied Economics, 33(1), 37-47.

Connell, R. W. (1998). Toplumsal cinsiyet ve iktidar (Çev. C. Soydemir). İstanbul: Ayrıntı Yayınları.

Croteau, J. M. (1996). Research on the work experiences of lesbian, gay, and bisexual people: An integrative review of methodology and findings. Journal of Vocational Behavior, 48(2), 195-209.

Demirdizen, D., Çınar, S., \& Kesici, M. R. (2012). İşyerinde cinsel yönelim ayrımcılı̆̆ı: LGB bireylere yönelik bir alan çalışması. IV. Sosyal Haklar Sempozyumu, 311-330.

Doğan, E. T. (2012). Bir sosyal politika meselesi olarak LGBT bireylerin çalışma yaşamında karşılaştığı ayrımcı pratikler. KAOS GL Dergisi, 127,13-15.

Doğan, E. T. (2015). İşgücü piyasasında cinsel yönelim ve cinsiyet kimliği ayrımcılığının sosyal politika açısından değerlendirilmesi. Y. Tar (Yay. Haz.), Çalışma Hayatında Ayrımcılık ve Ayrımcılığa Karşı Mücadele içinde, 57-76.

Doğrul, H. G. (2007). Kentsel alanlarda kadın işgücü arzının belirleyicileri ve kadın işgücü arzının ücret yapısı üzerindeki etkisi: Türkiye üzerine bir uygulama. Dumlupınar Üniversitesi, Sosyal Bilimler Enstitüsü, Yayınlanmamış Doktora Tezi, Kütahya

Demirel, Y. (2011). İşyerinde ayrımcılık: Kavramsal bir inceleme. Tisk Akademi, 11, 66-87.

Drydakis, N. (2009). Sexual orientation discrimination in the labour market. Labour Economics, 16(4), 364-372.

Foucault, M. (2012). Cinselliğin tarihi (Çev. H. U. Tanrı̈ver). İstanbul: Ayrıntı Yayınları.

Goldman B. M., Gutek B. A., Stein J. H., Lewis K. (2006). Employment discrimination in organizations: Antecedents and consequences. Journal of Management, 32, 786-830.

Göçmen, i., \& Yılmaz V. (2016). Exploring perceived discrimination among LGBT individuals in Turkey in education, employment, and health care: Results of an online survey. Journal of Homosexuality, 64(8), 1052-1068. 
Göregenli, M., \& Karakuş, P. (2011). Turkiye'deki LGBT bireylerin günlük yaşamlarında maruz kaldığı heteroseksist ayrımcı tutum ve uygulamalar. A. Erol (Ed.), Antihomofobi kitabı-3 içinde (ss. 53-62). Ankara: Ayrıntı Basımevi.

Göregenli, M., \& Serdengeçti, T. Ş. (2017). Özel sektör çalışanı LGBTi’lerin yüzde 65'i ayrımcılığa uğruyor! http://www.kaosgldernegi.org/resim/yayin/dl/ozel_sektr_raporu_2017.pdf (Erişim tarihi: 21 Mart 2019).

Griffin, R. P. (1992). Why doesn't performance pay work? Health Manpower Management, 18(4).

Güner, U., Kalkan, P., Öz, Y., Özsoy,E. C. \& Söyle, F. (2011). Türkiye'de cinsel yönelim veya cinsiyet kimliği temelinde ayrımcılığın izlenmesi raporu. İstanbul Bilgi Üniversitesi İnsan Hakları Hukuku Uygulama ve Araştırma Merkezi

Jackson, S., \& Scott, S. (2012). Cinselliği kuramlaştırmak (Çev. S. Serezli). Ankara: NotaBene Yayınları.

Kaos GL, (2015). Türkiye'de LGBT yurttaşlara yönelik insan hakları ihlalleri [Broşür]. IGLHRC ve Pembe Hayat LGBTT Dayanışma Derneği, İstanbul

Kaos GL, (2018). Sıkça sorulan sorular [Broşür]. Ankara, Ostim: Ayrıntı Basınevi

Kılıçaslan, S. C., \& Akkuş, P. (2016). Türkiye'de heteropatriarkal sistem baskısı altında LGBTi'lerin sosyal hizmet ihtiyaçları. Eğitim Bilim Toplum Dergisi, 14(56), 28-54.

Kuş, E. (2003). Nicel- nitel araştırma teknikleri. Ankara: Anı Yayıncılık

Kutlu, D. (2009). Çalışma yaşamında ayrımcılık: Gey çalışanlar örneği. Sosyal Dışlanma ve Sosyal Hizmet Sempozyumu Bildiriler Kitabı.

Lahey, J. N. (2005). Do older workers face discrimination? An Issue in Brief Center for Retirement Research at Boston College. No.33.

Levine, M. P., \& Leonard, R. (1984). Discrimination against lesbians in the work force. Journal of Women in Culture and Society, 9(4), 700-710.

LGBTQA+ Resource Center, (2018). LGBTi’lerin sosyal hizmet ihtiyaçları. Eğitim Bilim Toplum, 14(56), 28-54. Be the Change, Resource Guide. https://Igbtqa.unl.edu/Resources/LGBTQA\%2B\%20Resource\%20Guide.pdf_(Erişim tarihi: 24 Mart 2019).

ICJ, (2009). Sexual orientation,gender Identityand International human rights law. Practitioners Guide No. 4, Switzerland.

Mishel, E. (2016). Discrimination against queer women in the US workforce: A résumé audit study. Socius: Sociological Research for a Dynamic World, 1 -13.

Özen Kutanis, R., \& Ulu, S. (2016). İşgücü piyasalarında ayrımcılığın kaynakları. Selçuk Üniversitesi Sosyal Bilimler Enstitüsü Dergisi, 35, 359-372.

Özgener, Ş. (2014). Iş ahlakının temelleri: Yönetsel bir yaklaşım. Ankara: Nobel Basım Yayım A.Ş.

Öner, A. (2015). Beyaz yakalı eşcinseller, işyerinde cinsel yönelim ayrımcılığı ve mücadele stratejileri. İstanbul: İletişim Yayınları.

Özbilgin, M., \& Tatlı, A. (2008). Global diversity management: An evidence based approach. Macmillan International Higher Education.

Öztürk, B. (2011). Sexual orientation discrimination: Exploring the experiences of lesbian, gay and bisexual employees in Turkey. Human Relations, 64(8), 1099-1118.

Ragins, B. R., Singh, R., \& Cornwell, J. M. (2007). Making the invisible visible: Fear and disclosure of sexual orientation at work. Journal of Applied Psychology, 92(4), 1103.

Rudman, L. A., \& Glick, P. (2008). The social psychology of gender: How power and intimacy shape gender relations. New York: Guilford Press.

Rubin, H. J., \& Rubin, I.S. (1995). Qualitative interviewing: The art of hearing data (2nd Ed.). London: Sage Publications.

SPoD, (2012). http://www.spod.org.tr/TR/Detay/55/3/2012-cinsel-yonelim-vecinsiyet-kimligi-temelli-insan-haklariihlalleri-izleme-raporu (Erişim Tarihi: 14.04.2019).

Tilcsik, A. (2011). Pride and prejudice: Employment discrimination against openly gay men in the United States. American Journal of Sociology, 117(2), 586-626.

Yıldırım, A., \& Şimşek, H. (2000). Sosyal bilimlerde nitel araştırma yöntemleri. Ankara: Seçkin Yayıncılık

Yıldırım, A., \& Şimşek, H. (2008). Sosyal bilimlerde nitel araştırma yöntemleri. Ankara: Seçkin Yayıncılık.

Yıldız, G. B. (2012). Çalışma hayatında LGBT bireylere yönelik ayrımcılığın önlenmesi ve ilgili mevzuat. KAOS GL Dergisi, 127, 36-37. 
Yılmaz, H. (2010). Biz'lik, öteki'lik, ötekileştirme ve ayrımcılık: Kamuoyundaki algılar ve eğilimler. Boğaziçi Üniversitesi, Rapor No. 10260048, İstanbul.

Yin, R. K (1984). Case study research: Design and methods. Beverly Hills, California: Sage Publications. 